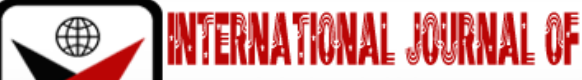 \\ בmRक
}

ISSN 2278-0211 (Online)

\section{The Effects of Inflation on Economic Growth in Nigeria}

\author{
Yussuff Rukayat Omobolanle \\ Lecturer, Department of Economics, Lagos State University, Ojo, Lagos, Nigeria
}

\begin{abstract}
:
The study investigated the effects of inflation on economic growth in Nigeria within the period 1990 to 2016. Secondary data for relevant variables were obtained from the CBN publications. The study adopted the use of unit root test, cointegration and VECM in estimating the data. The study found that inflation does not have significant effect on economic growth between 1990 and 2016 based on the significant level which was greater than 0.05. The result also shows that inflation is not significant in explaining the changes in economic growth between 1990 and 2016.The examination of their causal relationship also proved to be non-existence as their probability values are higher than the benchmark of 0.05. Meanwhile, a long run and short analysis was also conducted. The findings shows that the previous year's deviation from long run equilibrium is corrected at an adjustment sped of $6.7 \%$. On the other hand, the short run coefficient of inflation is 0.070590 . This suggest that holding other variables constant, in the short run, a percent change in inflation will on the average lead to 0.07 percent increase in economic growth (EGR) in Nigeria. Meanwhile, changes in the dependent variable (EGR)were explained by $35 \%$ changes in the independent variable (INF). It is thus recommended that government should push for dynamic monetary policy that can mitigate against inflation, when it becomes inimical on the long run.Since there is a long run relationship between inflation and economic growth, the government should not be much concerned on the impact of inflation but rather push for inclusive growth policies that can result in all round growth.
\end{abstract}

Keywords: Economic growth, inflation, VECM

\section{Introduction}

The attainment of sustainable economic growth and stability of prices is a central objective of macroeconomic policy in most economies in general and Nigeria in particular.Inflation is general perceived as a persistent or continuous rise in general price level. Inflation exists when the price level is rising for a number of time periods. The major objective of monetary policy is stability of prices because empirical evidence shows that with price stability, sustainable growth can be achieved. Price stability implies that the rate of change of the general price level does not generate a problem to agents.

Theoretically and empirically, inflation continues to generate a debate as well as interest among scholars because of its stringent effects on economy growth (Hossain and Chowdhury, 1996). The reduction in growth rate experienced by the Latin American Countries as a result of high inflation rate in the 1970s lead to the debate that inflation rather than having a positive effect on growth impact the economy negatively. This issue has become perennial and it has attracted a lot of studies. The contention in the literature is whether inflation is beneficial or detrimental to economic growth. To the Structuralists, inflation is indispensable for economic growth while the monetarists are of the view that inflation constitutes an obstacle to economic growth. Two aspects of the debate have to do with the nature of the relationship if one exists and, the direction of causality. Inflation which is a result of increasing aggregate demand which in turn leads to increase in total production was not considered as detrimental to the growth and development of an economy until Phillips proposed the hypothesis that rising inflation rate positively impacts the economy through reduction in unemployment rate.

The Nigerian economy has gone through many fundamental structural changes over the years. Evidence abounds to indicate that the dramatic structural change did not lead to any appreciable economic growth.Rather the economy is indicative of a depression partly attributable to the global economic recession of the early 80s and partly to the economy over reliance on oil revenues and gross economic mismanagement by successive governments (Biobaku, 2004).

Nigerian economy experiences with inflation are not really the problem, but the fact that the situation has become a crisis.

The Central Bank of Nigeria (CBN) came into existence in 1959. One of the dominant policies aim of the CBN has been inflation targeting and exchange rate policy due to the believe that these are essential tools of achieving macroeconomic stability (Aliyu and Englema, 2009). Different policy measures were introduced by various governments to curb inflation, despite this inflation has continued to be an obstacle to economic growth in Nigeria.

\subsection{Research Questions}

The questions then are:

- What is the causal relationship between inflation and economic growth in Nigeria? 
- What is the identified short-run and long-run relation between inflation and economic growth in Nigeria?

- Does persistent inflation indicate decline in the economy?

\subsection{Objectives of the Study}

The aim is to investigate the effects inflation on the economic growth of Nigeria by examining the following specific objectives:

- Determine the causal relationship between inflation and economic growth in Nigeria.

- To investigate the short-run and long-run relationship between inflation and economic growth in Nigeria.

- To determine whether persistent inflation causes decline in an economy.

\subsection{Research Hypothesis}

The hypothesis stated in null form are:

- $\mathrm{H}_{0}$ : Inflation rate has no significant effect on economic growth in Nigeria.

- $\mathrm{H}_{0}$ : Causal relationship between inflation and economic growth in Nigeria is non-existence.

- $\mathrm{H}_{0}$ : There exists no short-run and long-run relationship between inflation and economic growth in Nigeria.

\section{Literature Review}

\subsection{Theoretical Literature on Inflation and Economic Growth Nexus}

The nexus between inflation and economic growth have generated an interest among scholars since the emergence of the classical economist to the modern economic theorists. Efforts were made to establish the demand and supply factors assumed to cause lags that manifest in higher prices of goods and services in an economy for a sustainable time period. The theories that expatiate on these factors include:

- The monetary theory or the modern quantity theory of money. According to the Monetarist, because only money matters, monetary instruments are very strong instruments of price and economic stabilization than fiscal policy. In the process of spending their cash balances, peoples demand for goods and services increases. The increase in the nominal quantity of money supplied to the economy is the aftermath of excess spending. Inflation is therefore always a monetary phenomenon.

- The Keynesian explanation of inflation is when total demand for goods and services exceeds aggregate supply and provisions of goods and services in the economy.The Keynesian model is based on aggregate demand (AD) and aggregate supply (AS) curves.In the Keynesian model, aggregate supply curve is upward sloping in the short-run so that the change in the demand side of the economy affects both the price and output (Dornbusch et al, 1996).

- The Cost Push Theory of Inflation explains that inflation is due to increase in the cost of production as a result of increase in wage and input prices increase.

- The structuralist school of thought assumed the major cause of inflation to be the structural rigidity. Structural inflation can occur in the service sector as a result of growth emanating from population growth and immigration.

\subsubsection{Neo-Classical Growth Theory}

The Neo-Classical growth theory as developed by Solow (1956) and Swan (1956)theorized that scientific innovation or technological change replaced investment growth (growth of capital) as the primary factor that explains long term growth and level of technological change is determined exogenously, that is, independent of all other factors including inflation. According to Gokal and Hanif (2004) the neo-classical theory of growth is built on the concept of diminishing returns to labour and capital separately and constant returns to both factors jointly. Technology, labour and capital are the determinants of output growth in the Neo-Classical Theory. Economists in neo-classical growth theory gave their own explanation about the relationship between inflation and economic growth. Mundell (1963), who was the first to enunciate his view, was of the opinion that inflation might permanently increase output growth rate by stimulating capital accumulation, because in response to inflation households would hold less in money balances and more in other assets.

Tobin (1965) also supported the view of Mundell that inflation is positively related to economicgrowth. He also argued that inflation causes individuals to change money into other interest earning assets, which leads to greater capital intensity and promote economic growth.

Stockman (1981) idea was that a negative relationship exists between inflation and economic growth contrary to Mundell's and Tobin's idea. According to Stockman an increase in the inflation rate results in a lower state level of output and people's welfare declines. In Stockman's model, money is a compliment to capital while Mundell and Tobin were for capital. While Tobin and Mundell supported positive relationship between inflation and economic growth, Stockman opined a negative relationship between inflation and economic growth. Sidrauskin (19670 posits that an increase in the inflation rate does not change the steady capital stock and economic growth, that is, no relationship exists between inflation and economic growth.

The Neo-Classical Theory of growth thus indicates a mix result on the association between inflation and economic growth. This inconclusiveness on the inflation-economic growth relationship is summarized by Friedman (1973) thus: 'historically, all possible combinations have occurred: inflation with and without development, no inflation with and without development'. 


\subsubsection{Endogenous Growth Theory}

In endogenous growth theories, economic growth is generated by factors within the production process such as economies of scale, increasing returns, or induced technological changes as opposed to exogenous factors such as increase in population. This theory assumes that technological process is endogenous which is contrary to the neo-classical growth theory. Other basic differences between the endogenous growth model and the neo-classical economies are that in the latter capital is assumed to be diminishing on return while the former assumes that marginal product of capital is constant.In endogenous growth theory, the rate of return on capital that is, human and physical capital determines the growth rate.

\subsection{Empirical Literature}

Earlier studies such as TunWai (1959) could not agree on the association between inflation and economic growth. Paul, Kearney and Chowdhury (1997) investigation of the inflation and economic growth in 70 countries out of which 48 are developing countries within the period1960-1989 indicated no causal relationship in 40 percent of the countries studied. Paul, Kearney and Chowdury (1997) however observeda bi-directional causality in 20 percent of the countries studied and a unidirectional relationship in the remaining countries.Bruno and Easterly (1998) empirical study findings show that a very high ratio of people perceive inflation to be harmful to growth align with the results of Dornbusch (1993), Dornbusch and Reynoso (1989), Levine and Renelt (1992) and Levine and Zervos (1993)

Symth (1992) study on the relationship between inflation and economic growth in the U. S. A. indicated a negative relationship by estimating that each one percentage point increase in the USA inflation reduces the country's annual growth rate by 0.223 percent. Another study on USA by Symth (1994) by estimating that each one percentage point increase in inflation caused a reduction of 0.158 percent in America's output.

Ozedemir (2010) examined the dynamic linkage between inflation uncertainty, inflation and output growth for the United

Kingdom, using quarterly data from 1957 Q2 to 2006 Q4. The vector auto-regressive fractionally integrated moving average (VARFIMA) was performed to examine the causal effect between inflation and growth. The result for the whole sample revealed that inflation uncertainty determines economic growth. In addition, output growth uncertainty has a positive impact on the inflation rate and output growth rate, but no relationship was found for the sub-period analysis. Barro (1995) study using a large sample covering more than 100 countries within the period 1960-1990 which indicated the existence of a significant negative relationship between inflation.

Bruno and Easterly (1995) result on the examination of the determinants of economic growth in 26 countries which experienced inflation crises during the period between 1961 and 1962 using annual CPI inflation indicated an inconsistent or somewhat inconclusive relationship between inflation and economic growth,

Faria and Carneiro (2001) examined the relationship between inflation and economic growth in Brazil using annual data for the period 1980-1995. Their findings using VAR methodology indicated a negative relationship between inflation and economic growth in the short-run and that inflation does not affect economic growth in the long-run. Their empirical results also confirm the super neutrality concept of money in the long-run.

Manoel (2010) investigated the relationship between inflation and economic growth in four Latin America using panel data from 1970-2007. By employing pooled ordinary least square fixed effect (FE) and random coefficient estimators (RC), result shows a significant negative relationship between inflation and economic growth.

Odhiambo (2011) study on the causal relationship between inflation, investment and economic growth in Tanzania indicated a unidirectional causal flow from inflation to economic growth.

Ziaur (2013) used time series data between 1976 and 2011 in order to investigate the inflation and economic growth relationship in Bangladesh. Using several econometrics techniques, results indicated a statistically significant negative relationship

Ferdinand and Isidore (2014) examined short-run and long-run inflation and economic growth nexus in Ghana using quarterly data from 1986 Q1 to 2012 Q4. By using co-integration and error correction mechanism, Ferdinand and Isidore (2014) found a negative relationship between inflation and economic growth.

Study conducted by Baharunshaha et al (2016) on inflation, inflation uncertainty and economic growth in 94 emerging and developing countries employed the system generalized method of moments (SGMM). Their study indicates the detrimental effect of inflation on economic growth in countries with no inflation crisis and that growth occurs when there is inflation uncertainty.

Studies on the relationship between inflation and economic growth in Nigeria include: Fabayo and Ajilore (2006) investigation of the existence of threshold effect in inflation-growth relationship on Nigeria using data for the period of 1970-2003. Their studies indicated a threshold inflationary level of 6 percent,

Omoke and Oruta (2010) using the data spanning from the period of 1970 to 2005 investigated the connection between inflation and economic growth in Nigeria. Using Johansen-Juselius co-integration technique, Omoke and Oruta (2010) study indicated a no co-integrating relationship between inflation and economic growth for Nigeria. They further employed VAR-Granger Causality at two lag periods and established unidirectional causality running from inflation to economic growth and therefore concluded that inflation indeed has an impact on growth.

Chimaobi (2010) using the VAR Granger Causality test investigated the inflation and economic growth relationship in Nigeria and found that a unidirectional causality exists from inflation to growth in Nigeria.

Umaru and Zubairu (2012) studied the impact of inflation on economic growth and development in Nigeria between 1970 and 2010 using the ADF technique and granger causality test. The empirical results indicated that all variables were stationary at first difference; and the results of causality showed that GDP granger causes inflation. 
Inyiama (2013) examine the link between inflation rate and economic growth in Nigeria for the period 1979 to 2009. Employing co-integration, error correction and granger causality test, the findings reveal that inflation has a significant negative impact on economic growth. He recommended that efforts should be geared towards keeping inflation at a single digit order to enhance economic growth.

Osuala, Osuala and Onyeike (2013) investigated the impact of inflation on economic growth in Nigeria from 19702011 using Augmented Dickey-Fuller (ADF) and Phillip- Perron (PP) test, Granger Causality test in the analysis. The variables used in the study include Real Gross Domestic Product (RGDP) and inflation rate. The result showed that bidirectional relationship exists between inflation and economic growth in Nigeria.

Bakare, Kareem and Oyelekan (2015), examined the effect of inflation rate on economic growth in Nigeria (19862014). The variables used are Gross Domestic Product (GDP) as a dependent variable and inflation rate as an independent variable. The result shows that inflation has a negative impact on economic growth. The Granger Causality shows that GDP cause inflation but inflation does not cause GDP.

\section{The Trend between Inflation and Economic Growth in Nigeria (1990-2016)}

The International Monetary Fund (IMF) World Economic Outlook Report (2011) indicated that the Nigeria's GDP tends to be low when the inflation rates are high. For example, in 1998 GDP growth rate was relatively amidst the high inflationary levels at the time. This could be positive impact of increased domestic productivities which was the major aim of SAP.

The rate of inflation continued to rise from 5.4 percent in 1987 to above double-digit nearing triple digits in some years, that is 50.5 percent in 1989 and dropped to 7.5 percent in 1990 as a result of an increase in the output growth of food. This was short-lived because from 1991the increase in domestic prices put inflation rate at 12.7 percent and by 1992 it was 44.8. Inflation rate was above 50 percent in periods between 1993 and 1995. This was reflected in low level of the Nigeria's GDP growth rate within the period which increased from 3.5 percent in the 1980s to 5.5 percent in the 1990 s. This increase in growth has been attributed to both demand and supply-side factors. This has been attributed to the 'Keynesian public expenditure-led growth (enhanced by oil revenues) or the increase in aggregate demand due to higher government spending and larger fiscal deficits, as the major cause of increasing growth rates (Egwaikhide, Chete and Falokun, 1994).

According to the Nigeria Economic Report (2013), expansionary fiscal policy resulted in excess demand in the economy as at the end of the 1980s, when output was above trend levels. The rate of inflation rose from 57.416 percent in 1993 to 72.721 percent in 1994 and 72.81 in 1995, which was the highest ever recorded in Nigeria with the corresponding value of the GDP growth rate of 2.09 percent, 0.91 percent and 0.307 percent within those years.

In 1996, the rate of inflation reduced drastically to 29 percent as a result of the contractionary (restrictive) monetary and fiscal policies adopted to quell the surge in inflation with a real output growth rate of 4.994 percent. By 1997, inflation rate was further reduced to 10.673 percent, 7.862 percent 1998 and 6.618 percent in 1999 and it remained relatively stable at 6.938 percent in year 2000 . Within this period, the value of GDP growth rate was 2.802 percent in year 1997, 2.716 percent in 1998, 0.474 percent in 1999 and gained slightly to 5.318 percent in year 2000.

The trend of inflation between 2001 and 2010 in Nigeria at average level is the double-digit rate but the GDP growth seems unimpressive which could be attributed to petroleum export proceeds. The inflation rate was 18.869 percent in 2001, 12.883 percent in 2002, 14.037 percent in 2003, 15.001 percent in 2004, 17.856 percent in $2005,8.218$ percent in 2006, 5.413 percent in 2007, 11.581 percent in 2008, 12.543 percent in 2009 and 13.72 percent in 2010 with the corresponding GDP growth rate within these years at 8.164 percent, 21.172 percent, 10.335 percent, 10.585 percent, 5.393 percent, 6.211 percent, 6.972 percent, 5.984 percent, 6.96 percent and 8.724 percent respectively.

In 2011 , the rate of inflation reduced to 10.8 percent and then increased to 12.2 percent in 2012 , 8.5 percent in 2013, 8.1 percent in 2014, 9.0 percent in 2015 and it skyrocketed to15.7 percent in 2016 having a corresponding GDP growth rate within these years as 4.9 percent in 2011, 4.3 percent in 2012, 5.4 percent in 2013, 6.3 percent in $2014,2.7$ percent in 2015 and -1.6 percent in 2016.

Despite the relatively good GDP growth rates in 2001 to 2010 the rise in inflationary rate in 2016 brought about a negative GDP growth rate.

\section{Research Method}

\subsection{Sources of Data}

Secondary data was obtained mainly from the Central Bank of Nigeria Statistical Bulletin for the period under study.

\subsection{Identification of Variables}

The variables used in the study are:

- Economic Growth Rate (EGR) which is the dependent variable. Economic growth is the rise in the inflationadjusted market value of goods and services produced in an economy within a time period. Economic growth rate refers the geometric annual rate of growth in GDP between the first and the last year over a period of time. It is traditionally measured as the percentage rate of increase in real gross domestic product. The increase in the production of these goods and services overtime is what lead to economic growth. The economic growth rate of nations is commonly compared using the ratio of the GDP to population or per capita income. 
- Real Gross Domestic Product (GDP) represents the total market value of all the goods and services provided in an economy within a specified period, conventionally, a year. It helps to measure the market size of an economy and assist in accentuate the economic performance of a country. An increase or improvement of GDP influences the status of unemployment in a country because it shows an improvement in economic activities hence changes in the productive sector, therefore, GDP has an inverse relationship with unemployment.

- The independent variables include: Inflation Rate (INF) which is usually expressed as a percentage. Inflation indicates a decrease in the purchasing power per unit of money (or of a nation's currency). The inflation rate is a measure of price inflation, the annualized percentage change in the general price index, usually the CPI overtime. Depending on the macroeconomic stance, it can either affect the economy positively or negatively.

- Unemployment Rate (UNEMP)has a negative effect on the economic wellbeing of the citizens hence impact negatively on the economy as a whole. Increase in unemployment lead to a decrease in national output

- Gross Fixed Capital Formation(GCFC) is a flow value, measured by the total value of a producer's acquisitions less disposal of fixed assets during the accounting period plus certain additions to the value of non-produced assetsrealised by the productive activity of institutional units. Gross fixed capital formation (GFCF) is the net increase in physical assets (investment less disposals) within the measurement period. It does not account for the consumption (depreciation) of fixed capital, and also does not include financial assets. The most important exclusion from GFCF is the sales and purchase of land because that only reflects a change of title of an existing land but it includes the value of land improvement. GFCF is expected to have positive and significant effects on Economic growth (EGR).

\subsection{Estimation Technique}

To examine the long run effect of inflation on economic growth, Vector Error Correction Mechanism (VECM) which incorporates both the long run and short run effect simultaneously was used. The beauty of VECM is that once variables are non-stationary but co-integrated, the estimates from VECM are more efficient than either the Ordinary least Square or orthodox VAR estimates. The VECM is also free of the associated endogeneity problem and the existing spurious inferences associated with OLS estimates. The OLS method is chosen because it's computational abilities and BLUE properties. It is fairly simple and it is also an essential component of most other estimation techniques (Green, 2010)The data are estimated with E-views 10

\subsection{Model Specification}

Following the empirical model stated in the theoretical framework, the economic growth-inflation nexus is specified as:

$E G R=f(I N F, U N E M P, G F C F, R G D P)$

Economic growth rate (EGR) is the dependent variable while, inflation (INF), unemployment (UNEMP), gross fixed capital formation (GFCF) and real gross domestic product (RGDP) are the independent variables.

Transforming the functional model above into an explicit econometric model in their natural log form implies that the constant and the error terms are introduced into the model, thus;

$E G R_{t}=\beta_{0}+\beta_{1} I N F_{t}+\beta_{2} U N E M P_{t}+\beta_{3} \operatorname{InGCFC} C_{t}+\beta_{4} I n R G D P_{t}+\varepsilon_{t}$

Where;

$\mathrm{EGR}=$ Economic growth rate

INF= Inflation Rate

UNEMP= Unemployment Rate

GCFC= Gross Fixed Capital Formation (GFCF)

RGDP $=$ Real Gross Domestic Product (RGDP)

$\beta_{0}$ is the constant of the model, and $\beta_{1} \ldots \beta_{5}$ are the coefficients of independent variables measuring the effects of a unit change in the value of the independent variable on economic growth rate.

\subsubsection{AprioriExpectation}

The expected relationship among the variables of the study is thus stated below using the parameters of each variable. The apriori expectation is thus;

$\beta_{1}<0, \beta_{2}<0, \beta_{3}>0$, and $\beta_{4}>0$,

\subsection{Presentation of Results}

\subsubsection{Descriptive Analysis}

The result of the descriptive analysis in Table 1 indicates that Real Gross domestic product (GDP) has an average value of 1.710000 billion naira while unemployment rate (UNEMPR)) has an average value of $6.37 \%$. Inflation rate (INF) has an average value of $18.76 \%$. The Gross Fixed capital Formation (GFCF) has an average value of 2.260 billion naira. Economic growth recorded an average value of 5.38\% between 1990 and 2016. Inflation has the highest standard deviation value of 17.75 over the period under study which is an indication of inflation variability in Nigeria though its deviation from mean is very low. The result shows that all the distributionsare positively skewed with the exception of unemployment (UNEMP) that is negatively skewed.

The value of kurtosis less than three is called platykurtic which means the distribution produces fewer or less extreme outliers than does the normal distribution. Thus, the Real Gross Domestic Product (RGDP), Unemployment Rate 
(UNEMP), Gross Fixed Capital Formation (GFCF) areplatykurtic since their kurtosis values are less than three: $2.39,2.47$ and 2.40 respectively. On the other hand, values greater than three are called leptokurtic which means that the distribution produces more outliers than the normal distribution. The Inflation Rate (INF) and Economic Growth Rate (EGR) are leptokurtic given the kurtosis values of 5.42 and 13.87 respectively. The result of the Jaque-Bera test indicated that most of the data sets are normally distributed. The minimum and maximum values of the variables show that RGDP within the period under study has a minimum value of 1.580 billion naira and maximum of 5.680 billion naira. The minimum and maximum values of UNEMP were 4.3\% and 7.6\% respectively between 1990 and 2016. Further analysis shows that the minimum and maximum values of INF are $5.38 \%$ and $72.84 \%$ while the minimum and maximum values of GFCF are 2.020 billion and 8.570 billion naira. Lastly EGR recorded -1.620 minimum growth rate and 33.740 maximum growth rate between 1990 and 2016.

\begin{tabular}{|c|c|c|c|c|c|}
\hline & RGDP & UNEMP & INF & GFCF & EGR \\
\hline Mean & 1.710000 & 6.374074 & 18.76926 & 2.260000 & 5.380370 \\
\hline Median & 6.770000 & 6.800000 & 12.22000 & 6.130000 & 4.410000 \\
\hline Maximum & 5.680000 & 7.600000 & 72.84000 & 8.570000 & 33.74000 \\
\hline Minimum & 1.580000 & 4.300000 & 5.380000 & 2.020000 & -1.620000 \\
\hline Std. Dev. & 1.840000 & 0.932982 & 17.75316 & 2.890000 & 6.594497 \\
\hline Skewness & 0.992033 & -0.806368 & 1.914774 & 1.085600 & 3.034457 \\
\hline Kurtosis & 2.394498 & 2.470022 & 5.424036 & 2.404756 & 13.87932 \\
\hline Jarque-Bera & 4.841047 & 3.242019 & 23.10906 & 5.701981 & 174.5902 \\
\hline Probability & 0.088875 & 0.197699 & 0.000010 & 0.057787 & 0.000000 \\
\hline Sum & 4.61000 & 172.1000 & 506.7700 & 6.100000 & 145.2700 \\
\hline Sum Sq. Dev. & 8.78000 & 22.63185 & 8194.537 & 2.170000 & 1130.672 \\
\hline Obs. & 27 & 27 & 27 & 27 & 27 \\
\hline
\end{tabular}

Table 1: Descriptive Analysis

Source: Author Computation (2019) using Eviews 10.0

\subsubsection{Correlation Analysis}

Table 2 shows the result of the correlation analysis which shows the degree of associations between dependent variable economic growth rate (EGR) and the independent variables (UNEMP, GFCF, INF and RGDP). The correlation resultis indicative of a negative relationship between INF and EGR (-0.27138). This is consistent with the theoretical relationship that exists between inflation and economic growth that is, inflation has a destabilizing effect on EGR. This also suggests that as inflation reduces, the economy is expected to grow while the economy declines in the presence of increased inflation rate. Most of the empirical studies have confirmed the negative and non-linear impact of inflation on economic growth especially beyond a certain threshold level (Khan and Senhadji 2001; Gillman and Kejak 2005). However, GFCF also has a negative correlation with EGR (-0.05852). This could be as a result of low rate of capital accumulation hence, it's not able to impact on economic growth positively. Meanwhile, UNEMP has a positive relationship with EGR (0.221161). This implies that all the independent variables have negative relationship with EGR except Unemployment (UNEMP).

\begin{tabular}{|c|c|c|c|c|c|}
\hline & RGDP & INF & GFCF & EGR & UNEMP \\
\hline RGDP & 1 & -0.36806 & 0.988929 & -0.01869 & -0.25062 \\
\hline INF & -0.36806 & 1 & -0.32274 & -0.27138 & 0.000331 \\
\hline GFCF & 0.988929 & -0.32274 & 1 & -0.05852 & -0.29102 \\
\hline EGR & -0.01869 & -0.27138 & -0.05852 & 1 & 0.221161 \\
\hline UNEMP & -0.25062 & 0.000331 & -0.29102 & 0.221161 & 1 \\
\hline
\end{tabular}

Table 2: Correlation Analysis

Source: Authors Computation (2019) using Eview 10.0

\subsubsection{Unit Root Test}

This study commenced its empirical analysis by first testing the properties of the time series used for analysis. This is imperative because most macroeconomic time series exhibit non-stationary behaviour in their level form, which often poses a serious problem to econometric analysis, leading to spurious result if appropriate measures are not taken (Johansen, 2011). Thus, the properties of the variables were tested using the Augmented Dickey-Fuller (ADF) test developed by Dickey and Fuller (1981). The DF Test is based on the following Equation

? $\mathrm{X}_{\mathrm{t}}=\mathrm{a}+$ ? $\mathrm{X}_{\mathrm{t}-\mathrm{l}}+\mathrm{Ut}$

Given the unit root null hypothesis, the coefficient of $X_{t-1}$ will not be statistically different from zero (i.e.,? $=0$ ). If there is no unit root, the series $X_{t}$ is said to be stationary in levels or integrated of order zero (denoted as I(0)). If there is a unit root, but differencing the series once makes it stationary, then it is said to be integrated of order one (denoted as I(1))(Gujarati,2005). Before the empirical results, a correlation analysis was performed to ascertain the correlation between the independent variables and the dependent variables. 


\begin{tabular}{|c|c|c|c|c|}
\hline Variables & ADF Statistic & Probability Values & 5\% MacKinnon Critical Values & Order of Integration \\
\hline EGR & -4.200135 & 0.0031 & --2.981038 & $I(0)$ \\
\hline GFCF & 2.323492 & 0.0403 & -3.029970 & $I(1)$ \\
\hline UNEMP & -2.250963 & 0.0347 & --2.981038 & $I(1)$ \\
\hline INF & -4.083748 & 0.0043 & -2.986225 & $I(1)$ \\
\hline RGDP & -4.073518 & 0.0044 & -2.986225 & $I(1)$ \\
\hline
\end{tabular}

Table 3: Unit Root Test

Authors Computation, 2019

The ADF results in Table 3 shows that Real Gross Domestic Product(RGDP), Gross Fixed Capital Formation (GCFC), inflation (INF)and unemployment rate (UENMP) are stationary at first differenceI (1) while Economic growth (EGR) is stationary at levels $I(0)$.

\subsubsection{Co-integration Test}

Following the ADF findings in 4.3 above which indicates that most of the variables of interest are of $I(1)$, there is need to test for co-integration among the variables used in the study. The Johansen multivariate co-integration technique was used instead of the Engel-Granger techniques. This was based on two reasons. First, most of the variables for analysis are $I(1)$ series, which is a precondition for the adoption of the Johansen technique and secondly, the model is multivariate model as specified in equation (1 and 2) above, consequently there is the possibility of having more than one co integrating vector in the model. This is against the Engel-granger technique which is only suitable for testing cointegration between two variables.

\begin{tabular}{|c|c|c|c|c|}
\hline No. of CE(s) & Eigenvalue & Statistic & Critical Value & Prob.** \\
\hline None $^{*}$ & 0.777058 & 109.2121 & 88.80380 & 0.0008 \\
\hline At most $1 *$ & 0.755616 & 73.19184 & 63.87610 & 0.0067 \\
\hline At most 2 & 0.502725 & 39.37544 & 42.91525 & 0.1081 \\
\hline At most 3 & 0.475681 & 22.60875 & 25.87211 & 0.1209 \\
\hline At most 4 & 0.256493 & 7.113036 & 12.51798 & 0.3329 \\
\hline \multicolumn{5}{|c|}{$\begin{array}{c}\text { Trace test indicates } 2 \text { cointegratingeqn(s) at the } 0.05 \text { level } \\
* \text { denotes rejection of the hypothesis at the } 0.05 \text { level } \\
* * \text { MacKinnon-Haug-Michelis (1999) p-values }\end{array}$} \\
\hline
\end{tabular}

The co-integration test showed that the null hypotheses of no co-integration between the variables are rejected, which implies that there is co-integration between Inflation (INF) and the components of the independent variables; Unemployment (UNEMP), Gross Fixed Capital Formation (GCFC), Economic Growth (EGR). From the result, there are at least two co integration equations among the variables.

\subsubsection{Short Run and Long Relationship between Economic Growth and Inflation Rate}

Given the existence of co integration among variables as indicated in Table 4, the dynamic Vector Error Correction model (VECM) was considered appropriate for the analysis of the long run effect of inflation rateon economic growth. The VECM result in Table 5 has two parts. The first part indicated the long run effects estimates while the estimates of the short run dynamic interaction that exists among the variables is indicated in the second part. The Second part is also linked with first part (long run relation) by the ECM. The speed of adjustment of the short run relation to unexpected shocks is measure from the ECM. It is measured as the effects of residual from the long run model. This long run feedback effect is indicated by significant ECM terms while the short run causality is measured by the significant coefficient on the individual variables. 


\begin{tabular}{|c|c|c|c|c|c|}
\hline \multicolumn{6}{|c|}{$\begin{array}{c}\text { Vector Error Correction Estimates } \\
\text { Date: 02/28/19 Time: 09:45 } \\
\text { Sample (adjusted): } 19922016 \\
\text { Included observations: } 25 \text { after adjustments } \\
\text { S.E in ( ) \& t-stat. in [] }\end{array}$} \\
\hline CointegratingEq: & CointEq1 & & & & \\
\hline EGR(-1) & 1.000000 & & & & \\
\hline \multirow[t]{3}{*}{$\operatorname{INF}(-1)$} & 0.069819 & & & & \\
\hline & $(0.31889)$ & & & & \\
\hline & [ 0.21894] & & & & \\
\hline \multirow[t]{3}{*}{ UNEMP(-1) } & -45.62564 & & & & \\
\hline & $(6.78851)$ & & & & \\
\hline & {$[-6.72101]$} & & & & \\
\hline \multirow[t]{3}{*}{$\operatorname{GFCF}(-1)$} & $-1.77 \mathrm{E}-09$ & & & & \\
\hline & $(1.5 \mathrm{E}-09)$ & & & & \\
\hline & {$[-1.16844]$} & & & & \\
\hline \multirow[t]{3}{*}{ RGDP(-1) } & $2.61 \mathrm{E}-10$ & & & & \\
\hline & $(2.4 \mathrm{E}-10)$ & & & & \\
\hline & [1.08126] & & & & \\
\hline $\mathrm{C}$ & 282.9006 & & & & \\
\hline Error Correction: & D(EGR) & $\mathrm{D}(\mathrm{INF})$ & $\mathrm{D}$ (UNEMP) & $\mathrm{D}(\mathrm{GFCF})$ & $\mathrm{D}(\mathrm{RGDP})$ \\
\hline \multirow[t]{3}{*}{ CointEq1 } & -0.073006 & 0.078357 & 0.007533 & $-2.06 \mathrm{E}+08$ & $-1.22 \mathrm{E}+09$ \\
\hline & $(0.05407)$ & $(0.08878)$ & $(0.00465)$ & $(4.5 \mathrm{E}+07)$ & $(2.4 \mathrm{E}+08)$ \\
\hline & {$[-1.35019]$} & {$[0.88259]$} & [1.61952] & {$[-4.62344]$} & {$[-5.18817]$} \\
\hline \multirow[t]{3}{*}{ D(EGR(-1)) } & -0.450813 & 0.097301 & -0.006730 & $-1.44 \mathrm{E}+08$ & $-3.81 E+08$ \\
\hline & $(0.19903)$ & $(0.32679)$ & $(0.01712)$ & $(1.6 \mathrm{E}+08)$ & $(8.7 \mathrm{E}+08)$ \\
\hline & {$[-2.26506]$} & {$[0.29774]$} & {$[-0.39305]$} & {$[-0.87536]$} & {$[-0.43879]$} \\
\hline \multirow[t]{3}{*}{$\mathrm{D}(\mathrm{INF}(-1))$} & 0.013595 & 0.108066 & 0.024979 & -39777567 & $-2.62 \mathrm{E}+08$ \\
\hline & $(0.12816)$ & $(0.21043)$ & $(0.01103)$ & $(1.1 \mathrm{E}+08)$ & $(5.6 \mathrm{E}+08)$ \\
\hline & {$[0.10607]$} & {$[0.51354]$} & [2.26565] & {$[-0.37642]$} & {$[-0.46887]$} \\
\hline \multirow[t]{3}{*}{ D(UNEMP(-1)) } & -0.757446 & 4.210718 & 0.041372 & $-9.14 \mathrm{E}+08$ & $-3.15 E+09$ \\
\hline & $(1.29184)$ & $(2.12111)$ & $(0.11113)$ & $(1.1 \mathrm{E}+09)$ & $(5.6 \mathrm{E}+09)$ \\
\hline & {$[-0.58633]$} & [1.98515] & {$[0.37228]$} & {$[-0.85777]$} & {$[-0.55971]$} \\
\hline \multirow[t]{3}{*}{$\mathrm{D}(\mathrm{GFCF}(-1))$} & $4.25 \mathrm{E}-10$ & $4.31 \mathrm{E}-10$ & $7.81 \mathrm{E}-12$ & 1.269581 & 6.578967 \\
\hline & $(4.9 \mathrm{E}-10)$ & $(8.0 \mathrm{E}-10)$ & $(4.2 \mathrm{E}-11)$ & $(0.40301)$ & $(2.13200)$ \\
\hline & [ 0.86867$]$ & {$[0.53762]$} & [0.18579] & [3.15026] & [3.08582] \\
\hline \multirow[t]{3}{*}{ D(RGDP(-1)) } & $-1.09 \mathrm{E}-10$ & $-6.82 \mathrm{E}-11$ & $-1.77 \mathrm{E}-12$ & -0.318038 & -1.546808 \\
\hline & $(9.8 \mathrm{E}-11)$ & $(1.6 \mathrm{E}-10)$ & $(8.4 \mathrm{E}-12)$ & $(0.08052)$ & $(0.42599)$ \\
\hline & {$[-1.11924]$} & {$[-0.42541]$} & {$[-0.21118]$} & [-3.94958] & {$[-3.63107]$} \\
\hline \multirow[t]{3}{*}{$\mathrm{C}$} & 0.738799 & -0.511081 & -0.036460 & $4.89 \mathrm{E}+09$ & $2.57 \mathrm{E}+10$ \\
\hline & $(1.84099)$ & $(3.02278)$ & $(0.15837)$ & $(1.5 \mathrm{E}+09)$ & $(8.0 \mathrm{E}+09)$ \\
\hline & {$[0.40131]$} & {$[-0.16908]$} & {$[-0.23022]$} & [3.22239] & [3.20545] \\
\hline R-squared & 0.278366 & 0.228034 & 0.360758 & 0.605095 & 0.647827 \\
\hline Adj. R-squared & 0.037821 & -0.029289 & 0.147677 & 0.473461 & 0.530436 \\
\hline Sum sq. resids & 1188.361 & 3203.757 & 8.794438 & $8.08 \mathrm{E}+20$ & $2.26 \mathrm{E}+22$ \\
\hline S.E. equation & 8.125273 & 13.34116 & 0.698985 & $6.70 \mathrm{E}+09$ & $3.54 \mathrm{E}+10$ \\
\hline F-statistic & 1.157232 & 0.886179 & 1.693057 & 4.596773 & 5.518546 \\
\hline Log likelihood & -83.74165 & -96.13851 & -22.41401 & -596.9996 & -638.6460 \\
\hline Akaike AIC & 7.259332 & 8.251081 & 2.353121 & 48.31996 & 51.65168 \\
\hline Schwarz SC & 7.600617 & 8.592366 & 2.694406 & 48.66125 & 51.99297 \\
\hline Mean dependent & -0.040000 & 0.107600 & -0.036000 & $2.46 \mathrm{E}+09$ & $1.51 \mathrm{E}+10$ \\
\hline S.D. dependent & 8.283429 & 13.14998 & 0.757122 & $9.23 \mathrm{E}+09$ & $5.17 \mathrm{E}+10$ \\
\hline \multicolumn{2}{|c|}{ Determinant resid covariance (dof adj.) } & $7.60 \mathrm{E}+43$ & & & \\
\hline \multicolumn{2}{|c|}{ Determinant resid covariance } & $1.47 \mathrm{E}+43$ & & & \\
\hline \multicolumn{2}{|c|}{ Log likelihood } & -1419.820 & & & \\
\hline \multicolumn{2}{|c|}{ Akaike information criterion } & 116.7856 & & & \\
\hline \multicolumn{2}{|c|}{ Schwarz criterion } & 118.7358 & & & \\
\hline \multicolumn{2}{|c|}{ Number of coefficients } & 40 & & & \\
\hline
\end{tabular}

Table 5: Long Run and Short Run Analysis.

Source: Author's Computation Using Eview

The results showed that the value of F-statistics is 1.157232 , with a probability value less than 0.05 . This demonstrated that the joint influence of the explanatory variables such as GFCF, INF, UNEMP and RGDP on Economic 
Growth (EGR) is statistically significant. The result also revealed that the value of the computed coefficient of multiple determination $\left(\mathrm{R}^{2}\right)$ is 0.27 , which implies that $27 \%$ of the variations in EGR are explained by the independent variables.

In the estimation, the results showed that the relationship between the variables satisfy the apriori expectation of the study, thus satisfying the stability condition of the study. This implies that the estimation results have the desired negative sign for each of the equation, and that the value or error correction model (ECM) is less than one which implies that it falls within the accepted region.As the estimates show in the long run, inflation has a long run relationship with economic growth. The estimates show from the adjustment coefficients that the previous year's deviation is corrected at a speed of 7.3percent. Furthermore, holding other variable constant, a percentage change in inflation (INF) will on the average lead to 0.01 percent increase in economic growth in the short run. Meanwhile, holding other variables constant, a percentage change in unemployment (UNEMP) will on the average lead to 0.75 percent decrease in economic growth in the short run. In addition, holding other variables constant, a percent change in Gross Fixed Capital Formation (GFCF) will on the average lead to 4.25 percent increase in economic growth (EGR). Lastly, a percent change in Real Gross Domestic Product (RGDP) will on the average lead to 1.09 percent decrease in economic growth in the short run.

\subsubsection{Post Estimation Evaluation}

To determine the suitability of the estimated model and to be sure of its overall significance and appropriate for policy control, a post estimation evaluation was conducted. The Wald Test which shows whether all the explanatory variables are able to jointly explain the changes in economic growth rate was conducted. That is, the significance of the model.

\begin{tabular}{|c|c|c|c|c|c|c|}
\hline \multicolumn{7}{|c|}{$\begin{array}{l}\text { VEC Residual Serial Correlation LM Tests } \\
\text { Date: 02/28/19 Time: } 10: 06 \\
\text { Sample: } 19902016 \\
\text { Included observations: } 25\end{array}$} \\
\hline \multicolumn{7}{|c|}{ Null hypothesis: No serial correlation at lag $\mathrm{h}$} \\
\hline Lag & LRE $^{*}$ stat & df & Prob. & Rao F-stat & df & Prob. \\
\hline 1 & 18.77812 & 25 & 0.8076 & 0.696461 & $(25,34.9)$ & 0.8253 \\
\hline \multicolumn{7}{|c|}{ Null hypothesis: No serial correlation at lags 1 to $\mathrm{h}$} \\
\hline Lag & LRE* $^{*}$ stat & df & Prob. & Rao F-stat & $\mathrm{df}$ & Prob. \\
\hline 1 & 18.77812 & 25 & 0.8076 & 0.696461 & $(25,34.9)$ & 0.8253 \\
\hline
\end{tabular}

Table 6: WALD Test

Table 6 above was aimed at estimating the presence of auto correction in the model. The probability value which examines the presence of auto correction was found to be higher than 0.05 . This suggests that the null hypothesis of no auto correction is accepted and hence it is concluded that the model does not suffer from the problem of autocorrelation.

\subsubsection{Test of Hypotheses}

4.5.7.1. Hypothesis One

- $\mathrm{H}_{0}$ :Inflation rate has no significant effect on the economic growth in Nigeria

\begin{tabular}{|c|c|c|c|c|}
\hline & $\begin{array}{r}\text { Dependen } \\
\text { Method: } \\
\text { Date: } 02 / 28 \\
\text { Sample } \\
\text { Included o }\end{array}$ & $\begin{array}{l}\text { ariable: EC } \\
\text { ast Square } \\
9 \text { Time: } 1 \\
9902016 \\
\text { ervations: }\end{array}$ & & \\
\hline Variable & Coefficient & Std. Error & t-Statistic & Prob. \\
\hline $\mathrm{C}$ & 7.272422 & 1.831072 & 3.971675 & 0.0005 \\
\hline INF & -0.100806 & 0.071503 & -1.409814 & 0.1709 \\
\hline R-squared & 0.073648 & \multicolumn{2}{|c|}{ Mean dependent var } & 5.380370 \\
\hline Adjusted R-squared & 0.036594 & \multicolumn{2}{|c|}{ S.D. dependent var } & 6.594497 \\
\hline S.E. of regression & 6.472714 & \multicolumn{2}{|c|}{ Akaike info criterion } & 6.644255 \\
\hline Sum squared resid & 1047.401 & \multicolumn{2}{|c|}{ Schwarz criterion } & 6.740243 \\
\hline Log likelihood & -87.69744 & \multicolumn{2}{|c|}{ Hannan-Quinn criter. } & 6.672797 \\
\hline F-statistic & 1.987575 & \multicolumn{2}{|c|}{ Durbin-Watson stat } & 1.716060 \\
\hline Prob(F-statistic) & 0.170915 & & & \\
\hline
\end{tabular}

Table 7: Effect of Inflation on Economic Growth

Source: Authors Computation (2019, Eviews10.0 Output) 
From Table 7 above the individual OLS estimates of -0.100806 coefficients and probability value of 0.1709 indicates that inflation rate (INF) has no significant effect on economic growth in Nigeria. Since the probability value is greater than 0.05 , the null hypothesis is not rejected and it is concluded that inflation does not have significant effect on economic growth between 1990 and 2016.The result also shows that inflation is not significant in explaining the changes in economic growth between 1990 and 2016.

\subsubsection{Hypothesis Two}

- $\quad \mathbf{H}_{\mathbf{0}}$ : Causal relationship between inflation and economic growth in Nigeria is non existence

To examine the causality between inflation and economic, granger causality was used to test the direction or no existence of causality between inflation and economic growth.

\begin{tabular}{|c|c|c|c|}
\hline \multicolumn{4}{|c|}{$\begin{array}{c}\text { Pairwise Granger Causality Tests } \\
\text { Date: 02/28/19 Time: 10:21 } \\
\text { Sample: } 19902016 \\
\text { Lags: } 1 \\
\end{array}$} \\
\hline Null Hypothesis: & Obs & F-Statistic & Prob. \\
\hline INF does not Granger Cause EGR & 26 & 0.31542 & 0.5798 \\
\hline \multicolumn{2}{|c|}{ EGR does not Granger Cause INF } & 0.15481 & 0.6976 \\
\hline
\end{tabular}

Table 8: Causal Relationship between Inflation and Economic Growth Source: Authors Computation (2019) using Eviews 10.0 Output

From the pair-wise causality test in Table 8, there is neither unidirectional or bidirectional causality between inflation rate (INF) and economic growth (EGR) in Nigeria between 1990 and 2016. Since their probability values are higher than 0.05 , the hypothesis is not rejected and it is concluded that causal relationship between inflation and economic growth in Nigeria is nonexistence within the period under study.

\subsubsection{Hypothesis Three}

- $\quad \mathbf{H}_{0}$ : There exist no short run and long run relationship between inflation and economic growth in Nigeria.

From the VECM estimates in Table 9, the adjustment coefficients of -0.677711 suggest that the previous year's deviation from long run equilibrium is corrected at an adjustment sped of $6.7 \%$. On the other hand, the short run coefficient of inflation is 0.070590 . This suggest that holding other variables constant, in the short run, a percent change in inflation will on the average lead to 0.07 percent increase in economic growth(EGR) in Nigeria. Meanwhile, change in the dependent variable (EGR) was explained by $35 \%$ changes in the independent variable (INF).

The study shows that there exists a short run and long run relationship between inflation and economic growth. Therefore, we reject the null hypothesis.

\begin{tabular}{|c|c|c|}
\hline \multicolumn{3}{|c|}{$\begin{array}{c}\text { Date: } 02 / 28 / 19 \text { Time: } 10: 25 \\
\text { Sample (adjusted): } 1992 \text { 2016 } \\
\text { Included Observations: } 25 \text { after Adjustments } \\
\text { S.E in ( ) \& t-stat. in [ ] }\end{array}$} \\
\hline CointegratingEq: & CointEq1 & \\
\hline EGR $(-1)$ & 1.000000 & \\
\hline \multirow[t]{3}{*}{$\operatorname{INF}(-1)$} & 0.212082 & \\
\hline & $(0.09355)$ & \\
\hline & [2.26713] & \\
\hline $\mathrm{C}$ & -9.468238 & \\
\hline Error Correction: & D(EGR) & D(INF) \\
\hline \multirow[t]{3}{*}{ CointEq1 } & -0.677711 & -0.694780 \\
\hline & $(0.29109)$ & $(0.54665)$ \\
\hline & {$[-2.32819]$} & {$[-1.27097]$} \\
\hline \multirow[t]{3}{*}{$\mathrm{D}(\mathrm{EGR}(-1))$} & -0.066458 & 0.319376 \\
\hline & $(0.22428)$ & $(0.42119)$ \\
\hline & {$[-0.29632]$} & [0.75827] \\
\hline \multirow[t]{3}{*}{$\mathrm{D}(\operatorname{INF}(-1))$} & 0.070590 & 0.216281 \\
\hline & $(0.11439)$ & $(0.21482)$ \\
\hline & {$[0.61708]$} & [1.00678] \\
\hline \multirow[t]{3}{*}{$\mathrm{C}$} & -0.071589 & 0.222522 \\
\hline & $(1.42712)$ & $(2.68006)$ \\
\hline & {$[-0.05016]$} & [0.08303] \\
\hline R-squared & 0.353238 & 0.094926 \\
\hline Adj. R-squared & 0.260844 & -0.034370 \\
\hline Sum sq. resids & 1065.064 & 3756.168 \\
\hline
\end{tabular}




\begin{tabular}{|c|c|c|}
\hline \multicolumn{3}{|c|}{$\begin{array}{c}\text { Date: } 02 / 28 / 19 \text { Time: } 10: 25 \\
\text { Sample (adjusted): } 19922016 \\
\text { Included observations: } 25 \text { after adjustments } \\
\text { S.E in ( ) \& t-stat. in [] }\end{array}$} \\
\hline S.E. equation & 7.121611 & 13.37405 \\
\hline F-statistic & 3.823152 & 0.734178 \\
\hline Log likelihood & -82.37240 & -98.12695 \\
\hline Akaike AIC & 6.909792 & 8.170156 \\
\hline Schwarz SC & 7.104812 & 8.365176 \\
\hline Mean dependent & -0.040000 & 0.107600 \\
\hline S.D. dependent & 8.283429 & 13.14998 \\
\hline \multicolumn{2}{|c|}{ Determinant resid covariance (dof adj.) } & 8223.911 \\
\hline \multicolumn{2}{|c|}{ Determinant resid covariance } & 5802.792 \\
\hline \multicolumn{2}{|c|}{ Log likelihood } & -179.2731 \\
\hline \multicolumn{2}{|c|}{ Akaike information criterion } & 15.14185 \\
\hline \multicolumn{2}{|c|}{ Schwarz criterion } & 15.62940 \\
\hline \multicolumn{2}{|c|}{ Number of coefficients } & 10 \\
\hline
\end{tabular}

\subsection{Discussion of Findings}

The tests were aimed at examining the effect of inflation on economic growth in Nigeria. There were the application re-estimation checks in order to ensure rge stability of the result. More importantly, the parameters estimate and the estimated regression were done to meet the assumptions of OLS, granger causality and VECM. A long run analysis was also conducted to determine the long run relationship between UNEMP, GFCF, INF RGDP and EGR. The explanatory variables explained about $27 \%$ and $35 \%$ of the variation in the dependent variables. The whole model was found to be statistically significant, that is, the independent variables were statistically significant in explaining the changes in economic growth (EGR). Therefore, the model logically suggests that the economic growth model is significant.

From the VECM result inTable 9, inflation has a long run relationship with economic growth while the previous year's deviation is corrected at a speed of 7.3 percent. Furthermore, holding other variable constant, a percentage change in inflation (INF) will on the average lead to 0.01 percent increase in economic growth in the short run. Meanwhile, holding other variables constant, a percentage change in unemployment (UNEMP) will on the average lead to 0.75 percent decrease in economic growth in the short run. In addition, holding other variables constant, a percent change in Gross Fixed Capital Formation (GFCF) will on the average lead to 4.25 percent increase in economic growth (EGR). Lastly, a percent change in Real Gross Domestic Product (RGDP) will on the average lead to 1.09 percent decrease in economic growth in the short run.

Hypothesis 1 sought to examine effect of inflation (INF) on economic growth (EGR) shows that inflation rate (INF) has no significant effect on economic growth in Nigeria. In conclusion, since probability value is greater than 0.05 . This suggests that changes in inflation rates do not necessarily affect economic growth in Nigeria. The result of the analysis confirms the non-rejection of the null hypothesis one and that inflation rate (INF) has no significant $\left(\mathrm{t}_{0.025}=-0.100806\right.$; $\mathrm{P}=$ 0.17090) effects on the economic growth process in Nigeria. In effect, the finding implies that change in inflation rate does not determine the extent of increase or decrease in the economic growth process between 1990 and 2016.

The result of this study is in tandem with the findings of Gbosi (2001) that the various sectors of the economy do not overlap with one another. Sectors which are expanding and experiencing a boom will lead to rise in price. Since prices are generally sticky, they will not decline in the contracting sector. The end result is an increase in the general price level leading to inflation. The result of this study also corroborates Chimobi (2010) findings which indicated no co-integrating relationship between the two variables.

Using Granger causality test, however, the study established unidirectional causality running from inflation to economic growth. Meanwhile, studies on the nonlinear relationship between inflation and economic growth argue that at low inflation levels, the relationship between inflation and economic growth is non-existent or positive while at higher levels of inflation, the relationship becomes significant and negative(Sani, 1999).

Hypothesis two, which sought to know if there is causal relationship between inflation and economic growth in Nigeria is nonexistence was not rejected because the p values were higher than 0.05.This implies that inflation does not cause economic growth between 1990 and 2016.The findings is consistent with Mohantyet al. (2011) who explored possible nonlinear relationship between inflation and growth in India using quarterly series and infer that the inflation rate of 4 to 5.5 per cent may be considered as an inflation threshold. Their empirical investigations do not find conclusive evidence of the existence of an inflation threshold. Meanwhile, Bassey and Onwioduokit (2011) used the framework of Li (2005) to investigate the relationship between inflation and economic growth as well as detect an appropriate threshold. Having established the presence of a negative relationship, they identify a statistically insignificant threshold level of 18 percent and establish that inflation rates below the threshold are growth propelling

Hypothesis Three: was meant to examine if there exist no short run and long run relationship between inflation and economic growth in Nigeria. The findings suggest that there is both short and long run relationship between inflation 
and economic growth in Nigeria. The findings are consistent with Mallik and Chowdhury (2001) findings in four South Asian Countries

\section{Summary, Conclusion and Recommendation}

\subsection{Summary of Finding}

The study examined the effect of inflation on economic, invariably examining the inflation-growth nexus has remained recurrent and has attracted substantial theoretical and empirical efforts. For instance, while the structuralists argue that inflation is crucial for economic growth, the monetarists posit that inflation is harmful to economic growth. Friedman (1973) noted that some countries have witnessed inflation period with and without development and vice versa (Sanni, 1999). The findings as well as the economic implications have been very instructive.

Specifically, the study found that inflation does not have significant effect on economic growth between 1990 and 2016 based on the significant level which was greater than 0.05 . The result also shows that inflation is not significant in explain the changes in economic growth between 1990 and 2016. While the examination of their causal relationship also proved non- existence as their probability values are higher than the benchmark of 0.05 . Meanwhile, a long run and short analysis was also conducted. The findings shows that the previous year's deviation from long run equilibrium is corrected at an adjustment sped of $6.7 \%$. On the other hand, the short run coefficient of inflation is 0.070590 . This suggest that holding other variables constant, in the short run, a percent change in inflation will on the average lead to 0.07 percent increase in economic growth (EGR) in Nigeria. Meanwhile, changes in the dependent variable (EGR) were explain by $35 \%$ changes in the independent variable (INF).

\subsection{Conclusion}

The examination of the effect of inflation on economic was to determine the level of effects on economic growth and the kind of relationship that exist between inflation and economic growth. Several findings from empirical point of view suggest that inflation has negative effect on medium to long term economic growth and showed that the relationship is influenced by countries with extreme values (either very high or very low inflation). They argued that inflation rates in excess of a critical value of 40 per cent are inimical to growth and went ahead to investigating only cases of discrete highinflation (40 per cent and above) crises. Thisyielded very robust empirical result that growth falls sharply during high inflation episodes and recovers rapidly as inflation falls to moderate levels. Bullard (1995) also provided firm evidence that the negative relationship between inflation and growth only manifests when inflation rates are in excess of some threshold levels. However, from the study, inflation do not seem to have significant effects on economic growth within the year under study though has long run relationship. This helps to understanding inflation play in determining the levels of economic growth.

\subsection{Recommendations}

Based on the findings of this study, the following recommendations are made;

- Since the findings suggest that inflation does not have significant effects on economic, government should push for dynamic monetary policy that can mitigate against inflation, when it becomes inimical on the long run.

- Inflation threshold which is the inflexion point for inflation-growth trade-off, need not be necessarily the inflation target, the inflation objective for monetary policy should be set lower than the inflation threshold.

- Where at some low levels, inflation may be positively correlated with growth, but at higher levels inflation is likely to be inimical to growth, hence the government should employ a policy mix to deflect the impact on economic growth.

- Since there is a long run relationship between inflation and economic growth, the government should not be much concerned on the impact of inflation but rather push for inclusive growth policies that can result in all round growth.

- Nonexistence of causality between inflation and economic growth shouldn't be taken with kid-glove but rather implement policies that can undermine the short run effect of inflation on economic growth in Nigeria.

\section{References}

i. Barro, R., (1996). Inflation and Growth, Federal Reserve Bank of St. Louis Review, vol. 78, pp. 153-169.

ii. Bruno, M., (1995). Does High Inflation really Lower Growth? Finance and Development, vol. 32, pp. 35-38.

iii. Bruno, M. \& W. Easterly, (1998). Inflation Crises and Long-Run Growth. Journal of Monetary Economics, vol. 41, pp. 3-26.

iv. Central Bank of Nigeria (1991). Statistical bulletin. Lagos: Central Bank of Nigeria.

v. Central Bank of Nigeria (2003) 'Annual Report and Statement of Accounts'.

vi. Central Bank of Nigeria (2003) 'CBN Statistical Bulleting'. Vol. 14 December.

vii. Central Bank of Nigeria (2015). Annual statistical report: Central Bank of Nigeria.

viii. Central Bank of Nigeria (2016). Annual statistical report: Central Bank of Nigeria

ix. Central Bank of Nigeria (2017). Statistical bulletin. Lagos: Central Bank of Nigeria.

x. Chimobi, O. P. (2010), 'Inflation and Economic Growth in Nigeria', Journal of Sustainable Development, Vol. 3, No. 2

xi. Dornbusch, R., 1993. Stabilization, Debt, and Reform: Policy Analysis for Developing Countries,New York: Harvester Wheatsheaf. 
xii. Dornbusch, R. \& A. Reynoso, (1989). Financial Factors in Economic Development', American Economic Review (Papers and Proceedings), vol. 79, pp. 204-209.

xiii. Engle, R.F. \&. B.S. Yoo, (1987). Forecasting and Testing in Co-Integrated Systems, Journal ofEconometrics, vol. 35, pp. 143-159.

xiv. Engle, R.F.\& B.S. Yoo, (1991). Cointegrated Economic Time Series: An Overview with New Results, in R.F. Engle and C.W.J. Granger, eds., Long-Run Economic Relationships, Oxford: Oxford University Press, pp.237-266.

xv. Engle, R.F. \& C.W.J. Granger, 1987. Co-integration and Error Correction: Representation, Estimation and Testing', Econometrica, vol. 55, pp. 1-87.

xvi. Faria, J. R. \&Carneiro, F.G. (2001). Does High Inflation Affect Growth in the Long and Short-Run? Journal of Applied Economics, 4(1): 89-105.

xvii. Fischer, S., (1993). The Role of Macroeconomic Factors in Economic Growth, Journal of Monetary Economics, vol. 32, pp. 485-512.

xviii. Granger, C.W.J., (1986). Developments in the Study of Co-Integrated Economic Variables.Oxford Bulletin of Economics and Statistics, vol. 48, pp. 213-228.

xix. Hossain, A. \& A. Chowdhury, 1996. Monetary and Financial Policies in DevelopingCountries, London: Routledge.

xx. Inyiama, O.I.(2013). Does Inflation Weaken Economic Growth? Evidence from Nigeria. European Journal of Accounting Auditing and Finance Research, 1(4), 139-150.

xxi. Johansen, S., 1988. 'Statistical Analysis of Cointegration Vectors', Journal of Economic Dynamics and Control, vol. 12, pp. 231-254.

xxii. Johansen, S. \& K. Juselius, 1990. 'Maximum Likelihood Estimation and Inference on Cointegration-with the Application to the Demand for Money', Oxford Bulletin of Economics and Statistics, vol. 52,pp. 169-210.

xxiii. Malik, G., \& Chowdhury, A. (2001) Inflation and Economic Growth: Evidence from Four South Asian Countries. Asian-Pacific Development Journal. Vol.8, No1, June.pp. 123-135

xxiv. Manoel, B. (2010). Inflation and economic growth in Latin America; some panel time series evidence(University of Pretoria Department of Economics working paper series). https://doi.org/10.1016/j.econmod. 2014.10.018

xxv. Osuala, A. E., Osuala, K. I. \&Onyeike, S.C. (2013). Impact of Inflation on Economic Growth in Nigeria: A Causality Test. Retrieved from www.transcampus. org/journals; www.ajol.info/journals/jorind, 11(1), 206-216.

xxvi. TunWai, U., (1959). The Relation between Inflation and Economic Development: AStatistical Inductive study,IMF Staff Papers, vol. 7, pp. 302-317.

xxvii. Smyth, D. J. (1992), 'Inflation and the Growth Rate in the United States' Natural Output', Journal of Applied Economics, 24.

xxviii. Smyth, D. J. (1994), 'Inflation and Growth', Journal of Macroeconomics, 16.

xxix. Smyth, D. J. (1995), 'Inflation and Total Factor Productivity in Germany', WeltwirtschaftlichesArchiv131: 403405

xxx. Umaru, A. \&Zubairu, A.A. (2012). Effect of Inflation on the Growth and Development of the Nigerian Economy: An Empirical Analysis. International Journal of Business and Social Science, 3(10), 183-191. 